\title{
Dissolved and suspended organic carbon in the Atlantic sector of the Southern Ocean. Stock dynamics in upper ocean waters
}

\author{
M. D. Doval ${ }^{1, *}$, X. A. Álvarez-Salgado ${ }^{1}$, J. M. Gasol ${ }^{2}$, L. M. Lorenzo' ${ }^{1}$, I. Mirón ${ }^{1}$, \\ F. G. Figueiras ${ }^{1}$, C. Pedrós-Alió ${ }^{2}$
}

${ }^{1}$ CSIC, Instituto de Investigación Mariñas, Eduardo Cabello 6, 36208 Vigo, Spain

${ }^{2}$ CSIC, Institut de Ciències del Mar, Passeig Joan de Borbó s/n, 08039 Barcelona, Spain

\begin{abstract}
Dissolved and suspended organic carbon (DOC and POC) distributions were studied in the undersampled Atlantic sector of the Southern Ocean during Cruise HE052 of the 'Bio Hespérides' in December 1998. The coastal waters of the ice edge, the Gerlache Strait, and the open-ocean waters of the Weddell Sea and the Drake Passage were sampled. The high correlation between chlorophyll $a$ (chl a), DOC and POC suggest that a considerable fraction (estimated at 15 to $30 \%$ ) of the organic matter available in the upper mixed layer of the different study regions is the product of synthesis and early degradation of planktonic primary production. Relatively low renewal times ( $\leq 2 \mathrm{wk})$ of this material, except in the Polar Front Zone ( $>5 \mathrm{wk}$ ), were deduced from measured primary/bacterial production rates. Maximum contributions of this potentially bioreactive organic carbon pool $\left(\mathrm{TOC}_{\mathrm{B}}\right)$ to the total organic carbon (TOC) were observed in the highly productive waters of the ice edge $(24 \%)$ and Gerlache Strait (30\%) regions, where high chl a levels and shallow upper mixed layers (due to marked salinity gradients) occurred. DOC represented 42 and $56 \%$ of $\mathrm{TOC}_{\mathrm{B}}$, in these regions, respectively. In contrast, $\mathrm{TOC}_{\mathrm{B}}$ comprised $\leq 20 \%$ of TOC in the less productive open-ocean waters of the Weddell Sea and Drake Passage, where DOC made up $\geq 65 \%$ of $\mathrm{TOC}_{\mathrm{B}}$. The Subantarctic Zone constituted an exception, with high chl a levels and a shallow upper mixed layer (due to marked temperature gradients): $29 \%$ of the organic carbon in the upper mixed layer was $\mathrm{TOC}_{\mathrm{B}}, 68 \%$ of which was in the dissolved fraction. Accumulation of DOC in the study regions points to a reduction in bacterial activity through mechanisms other than substrate limitation.
\end{abstract}

KEY WORDS: Dissolved and suspended organic carbon · Primary and bacterial production $\cdot$ Carbon renewal time $\cdot$ Drake Passage $\cdot$ Southern Ocean

\section{INTRODUCTION}

Nearly all the organic carbon in the oceans originates from phytoplankton primary production (Kirchman et al. 1993). This phytogenic material can be subsequently mineralised in situ, transferred through the food web, transported by horizontal circulation, or carried to deep waters by fast-sinking particles, vertical

\footnotetext{
*E-mail: marylo@iim.csic.es
}

migration of zooplankton and downward mixing of dissolved (DOC) and suspended (POC) organic carbon (Copin-Montégut \& Avril 1993, Carlson et al. 1994). Up to the late 1980s new production estimates in the oceans were based on the assumption of a steady-state balance between the downward flux of sinking particulate organic matter and the upward flux of inorganic nutrients at the base of the photic layer (Eppley \& Peterson 1979). During the 1990s, special attention was paid to dissolved organic matter (DOM) because of its contribution to the recycling and export of primary 
production (e.g. Toggweiler 1989, Bronk et al. 1994). Accordingly, before the late 1980s most papers dealing with organic matter only presented POC, whereas during the 1990s they focused only on DOC. However, the key role of the POC pool in DOM studies - linked to DOM recycling and export processes, particularly in autotrophic systems - has only been considered in some recent DOM works (Carlson et al. 1998, Bodineau et al. 1999, Doval et al. 1999, Hung et al. 2000).

The present study focuses on DOC and POC cycling in the undersampled Atlantic Sector of the Southern Ocean, covering a wide variety of contrasting hydrographic conditions during December 1998. The Southern Ocean is the world largest high-nutrient/lowchlorophyll region and a known sink for atmospheric $\mathrm{CO}_{2}$ (Le Fèvre \& Tréguer 1998). Nowadays, the Southern Ocean is viewed as a mosaic of subsystems, some of which are highly productive whereas others are dominated by long periods of heterotrophy. According to the mechanism that controls nitrogen uptake, and hence phytoplankton production, 4 subsystems have been identified by Trèguer \& Jacques (1992): the highly productive Coastal and Continental Shelf Zone (CCSZ), Seasonal Ice Zone (SIZ) and Polar Front Zone (PFZ), and the less-productive Permanently Open Ocean Zone (POOZ). We sampled all of these during Cruise HE052 of the 'Bio Hespérides'. From south to north, we occupied the coastal zone of the Gerlache Strait, the Weddell Sea ice edge and open waters, and the Antarctic, Polar Front and Subantarctic Zones across the Drake Passage (see Fig. 1). Enhanced primary production regions associated with melting ice and with the frontal structures of the Antarctic Circumpolar Current (ACC) were sampled. In addition, the Weddell-Scotia Confluence (WSC) was visited, where eastward-flowing ACC and Weddell Sea waters mix with continental shelf waters from the Weddell Sea (Withworth et al. 1994).

The role of DOM in the Southern Ocean has been the subject of several recent studies, covering wide latitudinal ranges in the Atlantic ( $6^{\circ} \mathrm{W}$ : Kähler et al. 1997), Indian $\left(62^{\circ} \mathrm{E}\right.$ : Wiebinga \& de Baar 1998), Australian $\left(140^{\circ} \mathrm{E}\right.$ : Ogawa et al. 1999) and Pacific $\left(170^{\circ} \mathrm{W}\right.$ and $170^{\circ} \mathrm{E}$ : Doval \& Hansell 2000) sectors of the ACC. We occupied the World Ocean Circulation Experiment (WOCE) Line SR1b in the Drake Passage (53 to $58^{\circ} \mathrm{W}$ ), recording for the first time DOC and POC stocks across this region, where the ACC enters into the Atlantic Sector of the Southern Ocean. Total organic nitrogen and phosphorus have also been recently measured by UV photo-oxidation along the same WOCE Line (Sanders \& Jickells 2000), allowing comparison with our data. In our study, we examined the relative contribution of the dissolved $(\varnothing<0.8 \mu \mathrm{m})$ and particulate $(\varnothing>0.8 \mu \mathrm{m})$ fractions to the organic carbon pool retained in surface ocean waters. In addition, we analysed the potential reactivity of DOC and POC in the upper ocean waters of the contrasting hydrographic regions visited during the cruise. A novel approach for determining the quality ('refractory', 'labile') of the DOC and POC pools, based on observed covariance between chlorophyll $a$ (chl a), DOC and POC profiles, was used. The calculations were complemented with measurements of primary and bacterial production rates, allowing a rough estimation of carbon renewal times.

\section{MATERIALS AND METHODS}

The sampling program was carried out during Cruise HE052 within the framework of the Research Project 'Diversidad, Heterotrofía, Autotrofía y Relaciones entre Microorganismos Antárticos (DHARMA)', conducted in December 1998 aboard the 'BIO Hespérides'. The cruise consisted of a hydrographic transect from the ice edge (Stn $1 ; 63^{\circ} \mathrm{S}$ ) across the Weddell Sea and Drake Passage to the north of the Subantarctic Front (Stn $\left.32 ; 55^{\circ} \mathrm{S}\right)$. We occupied WOCE Line SR1b across the Drake Passage (Stns 12 to 32). In addition, Stns 47 (ice edge), 49 (Western Gerlache Strait) and 58 (Eastern Gerlache Strait) were also visited (Fig. 1) to study the diel variation of DOC/POC stocks and primary/bacterial production rates. We will include the data from these stations because they are representative for the highly productive ice edge and coastal zones and complement the database generated in Sampling Line SR1b. However, we will not go deeply into the diel cycles, since these will be the subject of a forthcoming paper.

Thermohaline parameters. Full-depth conductivitytemperature-depth profiles were obtained at each station with a Mark IIIC probe attached to a rosette sampler fitted with 24 Niskin bottles of $10 \mathrm{l}$ with internal closure (General Oceanics). The gear was also equipped with a Sea Tech fluorometer. Temperature and salinity were used to characterise water masses and to define the surface layer thickness and stability by means of the squared Brunt-Väisälä frequency $\left(N^{2}\right)$ in the different hydrographic regions occupied during the cruise. Following Millard et al. (1990), $N^{2}$ can be calculated as:

$$
N^{2}=\frac{g}{\rho}\left(\frac{\Delta \rho}{\Delta z}\right)
$$

where $g$ is gravity acceleration and $\rho$ and $\Delta \rho / \Delta z$ are mean density and density gradient over the depth interval $\Delta z(=5 \mathrm{~m})$, respectively. The pycnocline is defined as the depth of the $N^{2}$ maximum, separating the surface layer (where chl $a$, POC and DOC accumulates) from the waters below. The relative contribution 


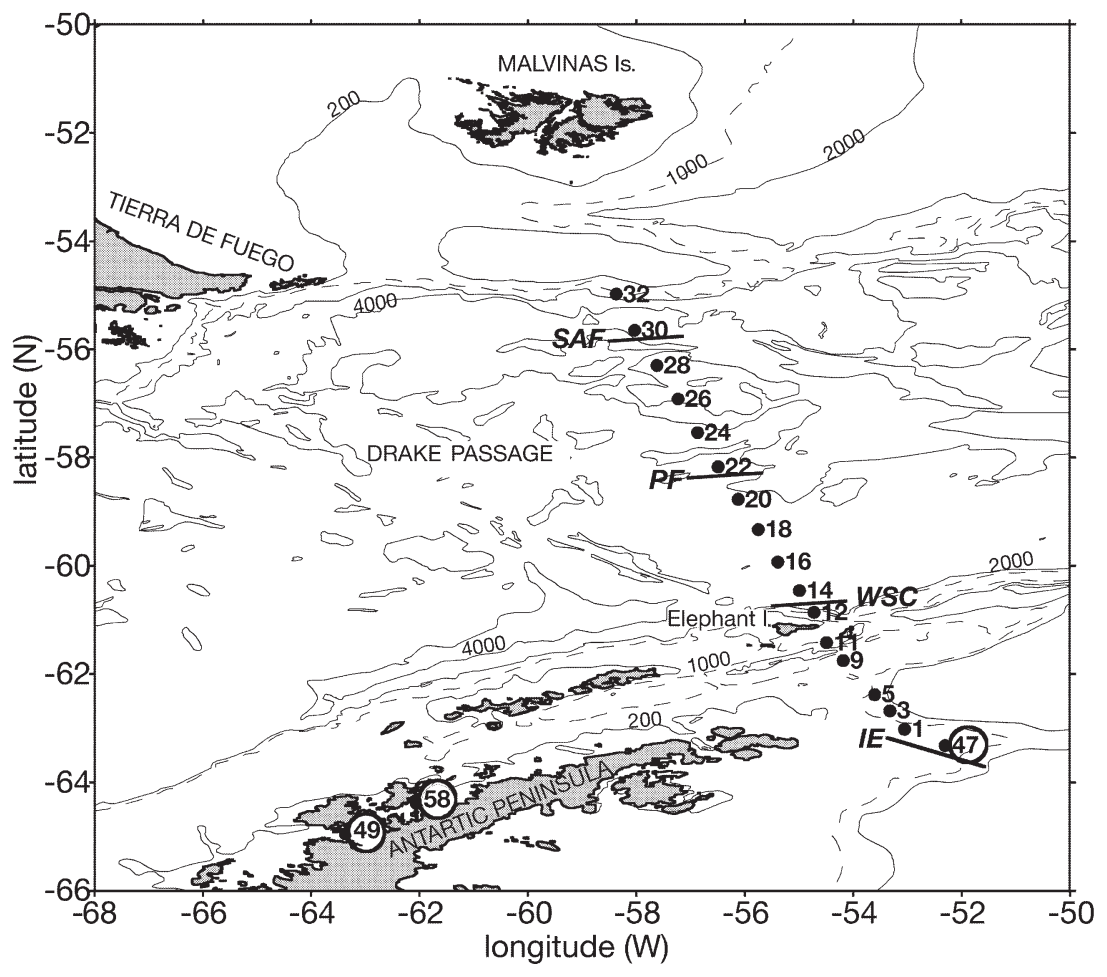

Fig. 1. Sampling sites during Cruise 'HE052' along the large-scale WOCE Line SR1b from the Weddell Sea ice edge to the northern end of Drake Passage (Stns 1 to 32), and 3 diel-cycle stations within the ice edge (Stn 47) and Gerlache Strait (Stns 49 and 58). IE: ice edge; WSC: Weddell-Scotia Confluence; PF: Polar Front; SAF: Subantarctic Front. Bathymetry $(\mathrm{m})$ is also shown the water column. Chl a profiles in the upper $100 \mathrm{~m}$ were estimated fluorometrically with a Turner Designs 10000R fluorometer (Yentsch \& Menzel 1963). Samples $(100 \mathrm{ml})$ were collected on $25 \mathrm{~mm} \varnothing$ $\mathrm{GF} / \mathrm{F}$ filters, frozen at $-70^{\circ} \mathrm{C}$ and left for $12 \mathrm{~h}$ in $90 \%$ acetone for pigment extraction. The fluorometer was calibrated with natural samples collected on the same cruise and measured spectrophotometrically.

DOC and POC concentrations were determined in the upper $250 \mathrm{~m}$ and the whole-water column, respectively. The DOC and POC fractions were separated with GF/F filters (equivalent pore size $0.8 \mu \mathrm{m})$. Seawater for the analysis of POC and suspended organic nitrogen (PON) was drawn from the Niskin bottles in 21 polycarbonate flasks (representative for particles <200 $\mu \mathrm{m}$ ). It was immediately filtered with an oil-less vacuum filtration system (filtration pressure $<0.3 \mathrm{~kg} \mathrm{~cm} \mathrm{~cm}^{-2}$ ) to collect the particulate material in $25 \mathrm{~mm} \varnothing \mathrm{GF} / \mathrm{F}$ filters (previously precombusted at $450^{\circ} \mathrm{C}, 4 \mathrm{~h}$ ). The filters were dried on silica gel and frozen at $-20^{\circ} \mathrm{C}$ until analysis in the laboratory. Measurements were carried out with a Perkin Elmer $2400 \mathrm{CHN}$ analyser. Acetanilide of temperature and salinity gradients to the stability of the surface layer is estimated as:

$$
\chi=\frac{1}{1-\left(\frac{\Delta T}{\Delta S}\right)\left(\frac{\alpha}{\beta}\right)}
$$

where $\alpha=-\frac{1}{\rho}\left(\frac{\partial \rho}{\partial T}\right)_{T=\langle T\rangle}$ and $\beta=\frac{1}{\rho}\left(\frac{\partial \rho}{\partial S}\right)_{S=\langle S\rangle}$ are the coefficients of thermal expansion and haline contraction, obtained from the equation of state of seawater (UNESCO 1985) respectively. They were calculated for the average temperature $(<T>)$ and salinity $(<S>)$ of the surface layer: $\Delta T=T_{\mathrm{P}}-T_{\mathrm{S}}$ and $\Delta S=S_{\mathrm{P}}-S_{\mathrm{S}}$. $T_{\mathrm{S}}$ and $S_{\mathrm{S}}$ are the temperature and salinity at the surface, and $T_{\mathrm{P}}$ and $S_{\mathrm{P}}$ are the temperature and salinity at the base of the pycnocline. Values of $\chi$ ranged from 0.0 (pure thermal stratification) to 1 (pure haline stratification); values greater than 1.0 indicate thermal inversion $(\Delta T<0)$, maintained through marked haline stratification. The value of $\chi$ indicates which thermohaline parameter is mainly responsible for the observed stability of the surface layer.

Chlorophyll $a$ and suspended and dissolved organic carbon measurements. Water samples were collected with 101 Niskin bottles at selected depths throughout was used to calibrate the system. The analytical error of the method is $\pm 0.1 \mu \mathrm{M} \mathrm{C}$ for POC and $\pm 0.04 \mu \mathrm{M} \mathrm{N}$ for PON.

Filtered DOC samples were collected into precombusted $10 \mathrm{ml}$ glass ampoules. After acidification with $\mathrm{H}_{3} \mathrm{PO}_{4}$ to $\mathrm{pH}<2$, the ampoules were heat-sealed and stored in the dark at $4{ }^{\circ} \mathrm{C}$, until analysed in the laboratory. After decarbonation of the sample by vigorous stirring, $200 \mu \mathrm{l}$ were injected into the vertical furnace of a 'Shimadzu TOC-5000', filled with a conditioned $0.5 \%$ Pt-coated $\mathrm{Al}_{2} \mathrm{O}_{3}$ catalyst at $680^{\circ} \mathrm{C}$. The system was standardised daily with potassium hydrogen phthalate. The concentration of DOC was determined by subtracting the system blank area from the average peak area and dividing by the slope of the standard curve. The system blank - obtained by frequent injection (every 4 to 6 samples) of UV-Milli-Q water - was equivalent to $10 \mu \mathrm{M} \mathrm{C}$. Precision of the measurements was about $\pm 1 \mu \mathrm{M} C$. The accuracy of our DOC measurements was tested daily with reference materials provided by J. Sharp (University of Delaware) and D. A. Hansell (BBSR, Bermuda). We obtained an average concentration of $45.1 \pm 0.7 \mu \mathrm{M} \mathrm{C}(\mathrm{n}=50)$ for the 'deep ocean' reference material (Sargasso Sea deep water, $2600 \mathrm{~m})$ and $0.4 \pm 0.7 \mu \mathrm{M} \mathrm{C}(\mathrm{n}=44)$ for the 'blank' 
reference material. The nominal values provided by the reference laboratories are $44.0 \pm 1.5$ and $0.0 \pm$ $1.5 \mu \mathrm{M}$ C, respectively.

Primary and bacterial production rates. Daily depthintegrated primary production ( $\mathrm{PP}, \mathrm{mg} \mathrm{C} \mathrm{m}^{-2} \mathrm{~d}^{-1}$ ) rates were calculated according to Figueiras et al. (1999), taking into account the spectral irradiance (using Eq. 3) because of the absence of light inhibition:

$\mathrm{PP}=D \cdot \int_{0}^{z_{1} \%} \operatorname{chla}(z) \cdot P_{m}^{B}(z) \cdot\left\{1-\exp \left[E_{\mathrm{PUR}}(z) / E_{k_{\mathrm{PUR}}}(z)\right]\right\} \cdot \mathrm{d} z$

where $D$ is daylength, $P_{m}^{B}$ is the chl-specific light-saturated rate of photosynthesis $\left(\mathrm{mg} \mathrm{C} \mathrm{mg}^{-1} \mathrm{chl} \mathrm{h}^{-1}\right)$, and $E_{k_{\text {PUR }}}\left(\mu \mathrm{mol}\right.$ photons $\mathrm{m}^{-3} \mathrm{~s}^{-1}$ ) is the light-saturation parameter for photosynthetically usable radiation (PUR) by phytoplankton. Both parameters were calculated from photosynthesis-irradiance $(P-E)$ curves obtained in lineal incubators and fitted to the model of Webb et al. (1974). As a function of depth of the photic layer, 3 to 5 depths were sampled at each station from the surface down to a depth of $1 \%$ incident light. Each incubator housed 14 subsamples collected in $75 \mathrm{ml}$ tissue-culture Corning flasks inoculated with $3.70 \times$ $10^{5} \mathrm{~Bq}(10 \mu \mathrm{Ci})$ of ${ }^{14} \mathrm{C}$-labeled bicarbonate. The samples were maintained at sea temperature by circulating water refrigerated with a Neslab digital temperature controller. Incubators were illuminated at the front by Osram tungsten-halogen lamps and the photosynthetic available irradiance $\left(E_{\mathrm{PAR}}\right)$ was measured using a Li-Cor cosine-corrected sensor (LI 190SA). The light quality did not vary among incubators. Samples were incubated for 2 to $3 \mathrm{~h}$. $E_{\mathrm{PUR}}(\mathrm{z})\left(\mu \mathrm{mol}\right.$ photons $\left.\mathrm{m}^{-3} \mathrm{~s}^{-1}\right)$ is the photosynthetic radiation usable by phytoplankton, and it was estimated according to Dubinsky (1980):

$$
E_{\mathrm{PUR}}(z)=\int_{400}^{700} a_{\mathrm{ph}}(z, \lambda) \cdot E(z, \lambda) \cdot \mathrm{d} \lambda
$$

where $a_{\mathrm{ph}}(z, \lambda)$ is the phytoplankton spectral absorption coefficient, and $E(z, \lambda)$ is the spectral irradiance at each depth determined from combining underwater measurements taken with a Li-1800UW spectroradiometer and incident irradiance at the sea surface measured on deck at 1 min intervals with a LI-190SA sensor. A $24 \mathrm{~h}$ average $E_{\text {PUR }}(z)$ was considered to remove from PP estimates the short time variability caused by clouds. Therefore $D=24 \mathrm{~h}$. For more details see Figueiras et al. (1999).

The production rate of heterotrophic bacteria (BHP) (assumed to include activities of bacteria and archaea) was estimated by the radioactive ${ }^{3} \mathrm{H}$-leucine incorporation method (Kirchman 1993) in $1.2 \mathrm{ml}$ samples incubated in Eppendorf vials (Smith \& Azam 1992). Forty nM leucine was added to 4 vials and 2 TCAkilled samples were used as controls. This leucine con- centration was found to be saturating in previous concentration-dependent incorporation experiments performed in these waters. The Eppendorf vials were incubated in the dark at temperatures within $\pm 0.5^{\circ} \mathrm{C}$ of in situ temperature; the incubations lasted from 2 to $5 \mathrm{~h}$ in accordance with results of linearity experiments. After incubation, the samples were precipitated with $50 \%$ TCA. On board, we processed the samples by centrifugation and counted the incorporated radioactivity with a Beckman scintillation counter.

Leucine incorporation rates were converted to carbon production rates by empirical conversion factors. Seawater cultures were established from around 201 of seawater that were filtered using a peristaltic pump. GF/A- and GF/F-filtered seawater was generated, mixed in equal parts, and dispensed into 21 bottles. The bottles were incubated in the dark for 8 to $10 \mathrm{~d}$ at nearly in situ temperature in duplicate bottles. Prokaryote counts were done daily by flow cytometry. Subsamples of $1.2 \mathrm{ml}$ were fixed with $1 \%$ paraformaldehyde $+0.05 \%$ glutaraldehyde (final concentrations) and left in the dark for $10 \mathrm{~min}$ prior to transfer to liquid nitrogen. They were subsequently transferred to a freezer $\left(-70^{\circ} \mathrm{C}\right)$. Back in the laboratory, samples were unfrozen, stained for $10 \mathrm{~min}$ with $2.5 \mu \mathrm{M}$ Syto13 (Molecular Probes) and run through a FACScalibur flow cytometer (Becton \& Dickinson), with a laser emitting at $488 \mathrm{~nm}$. Samples were run at low speed (approximately $22 \mu \mathrm{min}^{-1}$ ) until 10000 events were acquired in log mode. We added $10 \mu \mathrm{l}$ per sample of a $10^{6} \mathrm{ml}^{-1}$ suspension of yellow-green $0.92 \mu \mathrm{m}$-diameter Polysciences latex beads as an internal standard. Prokaryotes were detected by their signature in a plot of side-scatter (SSC) versus green fluorescence (FL1), as described by Gasol \& del Giorgio (2000). The relationship between yellow fluorescence and bacterial size presented in Gasol \& del Giorgio's study was used to derive bacterial biomass from abundance data; we used the integrative method (Riemann et al. 1987), comparing total biomass produced and total leucine incorporated to derive the leucine conversion factors. These factors ranged between 1.5 and $2.6 \mathrm{~kg} \mathrm{C} \mathrm{mol}^{-1}$ leu.

\section{RESULTS AND DISCUSSION}

\section{Contrasting hydrographic regions occupied during Cruise HE052}

The quasi-meridional line from Stns 1 to 32 covered 5 contrasting hydrographic regions (Fig. 1), distinguishable by their distinct thermohaline parameters: the ice edge (IE; Stn 1), the Weddell Zone (WZ; Stns 3-12), the Antarctic Zone (AZ; Stns 14-20), the 
Polar Front Zone (PFZ; Stns 22-28) and the Subantarctic Zone (SAZ; Stns 30-32).

The IE, sampled in more detail at Stn 47, displayed surface temperature and salinity values around $-1{ }^{\circ} \mathrm{C}$ and 34.1 respectively (Figs $2 \mathrm{a}, \mathrm{b} \& 3 \mathrm{a}$ ), slightly modified by ice-melting compared with the waters below. Icemelting contributes chl $a$ and organic matter produced within the ice (Smith \& Nelson 1986, Melnikov 1998) and increases water-column stratification, favouring accumulation of materials and enhancing photosynthetic activity (Sullivan et al. 1988, Murphy et al. 1998). A maximum chl a $\left(>3 \mathrm{mg} \mathrm{m}^{-3}\right)$ was recorded in the upper mixed layer (Figs 2c \& 3b). The pycnocline was at about $50 \mathrm{~m}$ and the stability of the surface layer, essentially maintained by haline stratification $(\chi=0.7)$, ranged from 0.2 to $0.4 \mathrm{~min}^{-2}$ (Fig. 2d).

Eastward-flowing Weddell Sea waters from the northern limb of the cyclonic Weddell gyre and continental waters from the Weddell Sea mix in the WZ. These waters are characterised by relatively low temperature $\left(<0^{\circ} \mathrm{C}\right)$ and high salinity (>34.1) (Fig. 2a,b). The WZ was the least stratified of all the hydrographic regions studied: average $N^{2}$ at the pycnocline was only $0.13 \mathrm{~min}^{-2}$ (Fig. 2d). This is due to vigorous vertical mixing (Gordon et al. 1977) and enhanced eastward velocities (García 1996) in this area. A surface chl a maximum ( $>1 \mathrm{mg} \mathrm{m}^{-3}$ ) was recorded at Stn 11, associated with a brief salinity minimum probably due to continental waters off Elephant Island (Fig. 2c). The surface layer extended to about $100 \mathrm{~m}$ and the reduced stability was mainly maintained by the salinity gradient.

The AZ is part of the ACC, which transports Antarctic Surface Water (AASW) from the Pacific Sector of the Southern Ocean across Drake Passage, resulting in a clear-cut difference between the physical characteristics of the IE and WZ. The AZ is characterised by a temperature around $0^{\circ} \mathrm{C}$ and a salinity of $<34.0$, with a well-developed temperature minimum embedded in the halocline (Gordon et al. 1977). Water-column stability was relatively high $\left(N^{2} \max .>0.4 \mathrm{~min}^{-2}\right.$; Fig. $\left.2 \mathrm{~d}\right)$, a result of the salinity gradient $(\chi>1)$. The pycnocline was at about $100 \mathrm{~m}$. A marked chl a maximum (>1 mg $\mathrm{m}^{-3}$ ) was observed at Stn 14, associated with the welldefined Weddell-Scotia Front (Fig. 2c). The relative stability maximum at Stn $18\left(>0.5 \mathrm{~min}^{-2}\right)$ was also accompanied by a relative surface chl a maximum (>0.6 $\mathrm{mg} \mathrm{m}^{-3}$ ).

The Polar Front (PF), at Stn $22\left(58^{\circ} \mathrm{S}\right)$, was marked by the northern limit of the $0^{\circ} \mathrm{C}$ isotherm at $100 \mathrm{~m}$ (Fig. 2a) in agreement with Nowlin et al. (1977). The PFZ, a region of transition between AASW and Subantarctic Surface Water (SASW), was characterised by a dramatic latitudinal gradient of temperature (from 1 to $5^{\circ} \mathrm{C}$ ) in the upper $400 \mathrm{~m}$ (Fig. 2a). Stratification was relatively weak (average $N^{2}$ max. $=0.19 \mathrm{~min}^{-2}$ ), evolving from haline $(\chi>0.8)$ to thermal control $(\chi<0.1)$ across the temperature gradient. The upper mixed layer of the PFZ was the deepest (average $133 \mathrm{~m}$ ) and showed the lowest chl a levels $\left(<0.5 \mathrm{mg} \mathrm{m}^{-3}\right)$ of all the hydrographic regions studied.

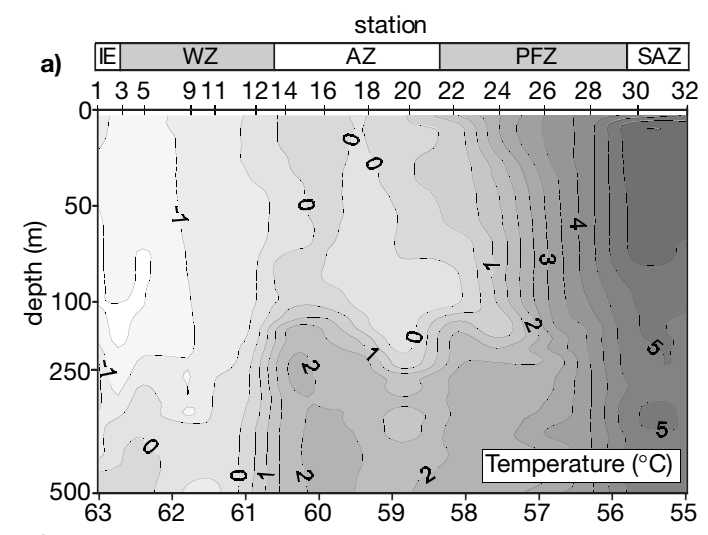

b)
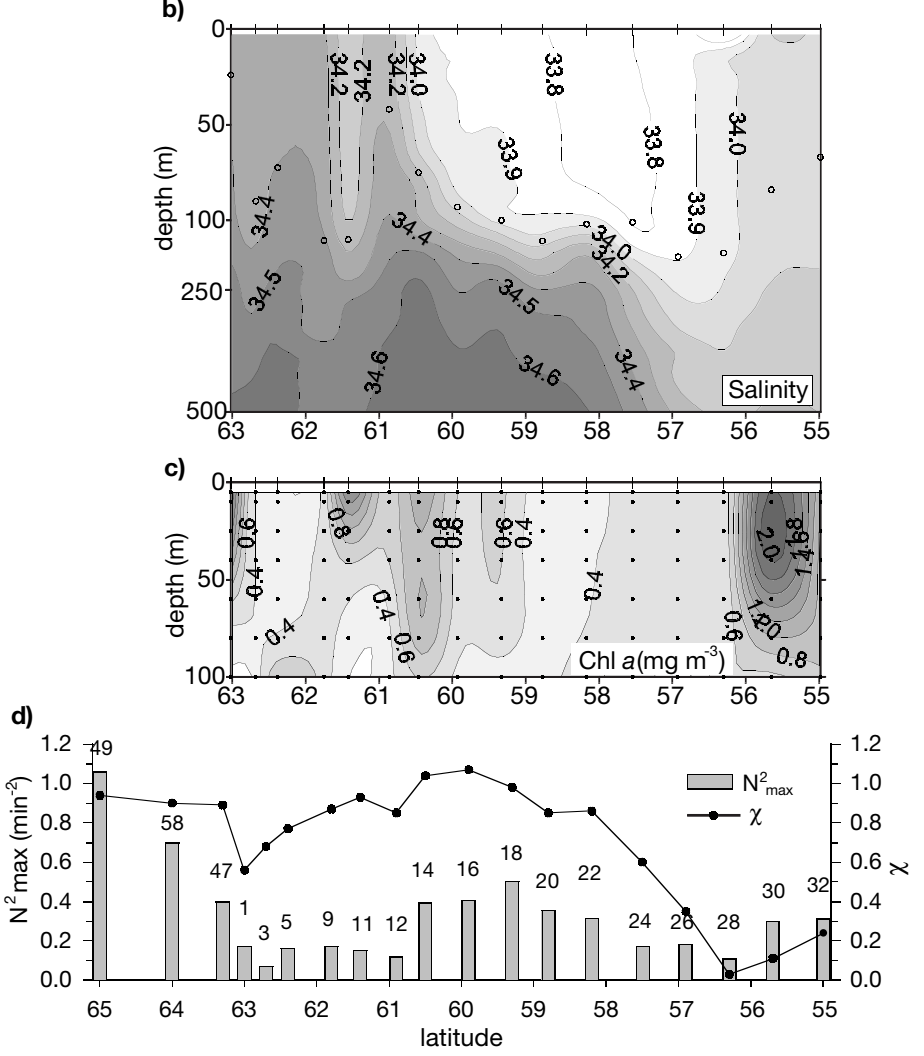

Fig. 2. Distributions of temperature (a), salinity (b) and chlorophyll a (c); and maximum stability, $N^{2}$ max, and temperature/salinity stability, $\chi$, in the study area. IE: Ice Edge Zone; WZ: Weddell Zone; AZ: Antarctic zone; PFZ: Polar Front Zone; SAZ: Subantarctic Zone. Open circles in (b) represent pycnocline depth, black dots in (c) sampling depths, numbers in (d) stations. Note that upper $100 \mathrm{~m}$ are expanded $(\times 2)$ compared to the 100 to $500 \mathrm{~m}$ depth range 

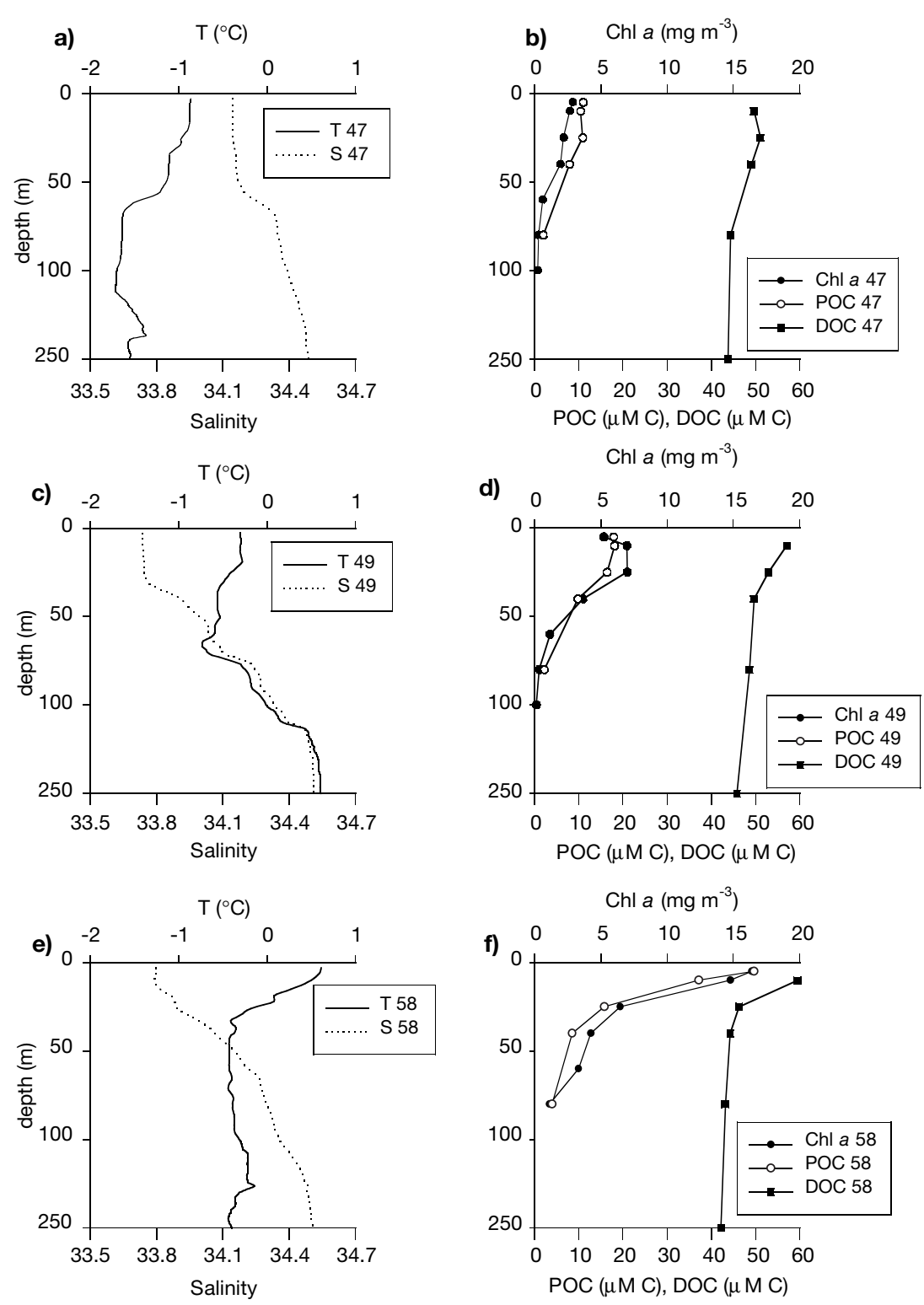

Fig. 3. $(a, c, e)$ Temperature and salinity (S) at the ice edge (Stn 47) and the diel-cycle (Stns 49 and 58: West Gerlache) stations respectively; (b,d,f) distribution of chl a, POC and DOC at the ice edge (47) and the diel-cycle (49 and 58) stations respectively. Note that upper $100 \mathrm{~m}$ are expanded $(\times 2)$ compared to the 100 to $250 \mathrm{~m}$ depth range. Only the midday CTD cast performed as part of the diel experiments is presented

In the northernmost side of the transect, where temperatures of 5 to $6^{\circ} \mathrm{C}$ and salinities around 34.0 were observed in the upper $100 \mathrm{~m}$ (Fig. 2a,b), the Subantarctic Front was crossed to enter the SAZ (Peterson \& Stramma 1991). This zone presented the highest chl a levels within Drake Passage (>1.5 mg $\mathrm{m}^{-3}$ : Fig. 2c). The pycnocline rose to $<80 \mathrm{~m}$ and the stability of the upper mixed layer increased to $0.30 \mathrm{~min}^{-2}$, mainly due to the vertical temperature gradient $(\chi<0.3$ : Fig. $2 d)$.
The Gerlache Strait was the sixth study region. The western (Stn 49) and eastern (Stn 58) ends were occupied (Fig. 1), and showed some differences in their temperature and salinity profiles; the surface layer of the western end was slightly cooler and fresher (Fig. 3c,e). Waters from the Bellingshausen and Weddell Seas, modified by the local glaciers, characterised this region (Niiler et al. 1991). The pycnocline was very shallow (from 20 to $50 \mathrm{~m}$ ), and stratification high $\left(N^{2} \max .>0.7 \mathrm{~min}^{-2}\right)$ and controlled by the salinity gradient $(\chi>0.9)$. Average chl a levels in the surface layer of Stns 49 and 58 were as high as 5 and $12 \mathrm{mg} \mathrm{m}^{-3}$ respectively (Fig. 3d,f).

\section{POC/chl a relationships: assessing quality of suspended materials}

The POC distributions resembled the chl a variability both in the Gerlache Strait (Fig. 3d,f) and along the quasi-meridional hydrographic line from the ice edge to the Subantarctic Zone (Figs 2c \& 4a). In general, a POC maximum accompanied each local chl a maximum in the upper mixed layer, except for the POC maximum at Stns 24 to 26 in the PFZ which displayed no distinct chl a signal.

The linear correlation between POC and chl $a$ over the upper $100 \mathrm{~m}$ (chl a sampling range) for the whole data set $(n=155)$ was very high $(r=0.92)$. However, to minimise the effect of water-mass mixing on the covariance between POC and chl $a$, an individual correlation analysis was performed for each hydrographic region (Table 1). The high correlation coefficients indicate a similar origin and fate for both parameters, i.e. that a substantial part of the suspended materials accumulated in the upper mixed layer are the products of synthesis and early degradation of phytoplankton primary production (e.g. Anderson 1995).

The contrasting coefficients ( $y$-intercept, slope) of the linear regressions (Model II; Sokal \& Rohlf 1995) computed for the 6 study regions are also presented in Table 1. The POC/chl a slopes of the linear regressions varied between $28 \pm 3 \mathrm{~g} \mathrm{C} \mathrm{g}^{-1} \mathrm{chl} a$ in the Gerlache Strait (maximal average chl $a$ in the upper mixed layer) and $113 \pm 15 \mathrm{~g} \mathrm{C} \mathrm{g}^{-1} \mathrm{chl} \mathrm{a}$ in the PFZ (minimum average chl a). Despite the possible interference of micro- 

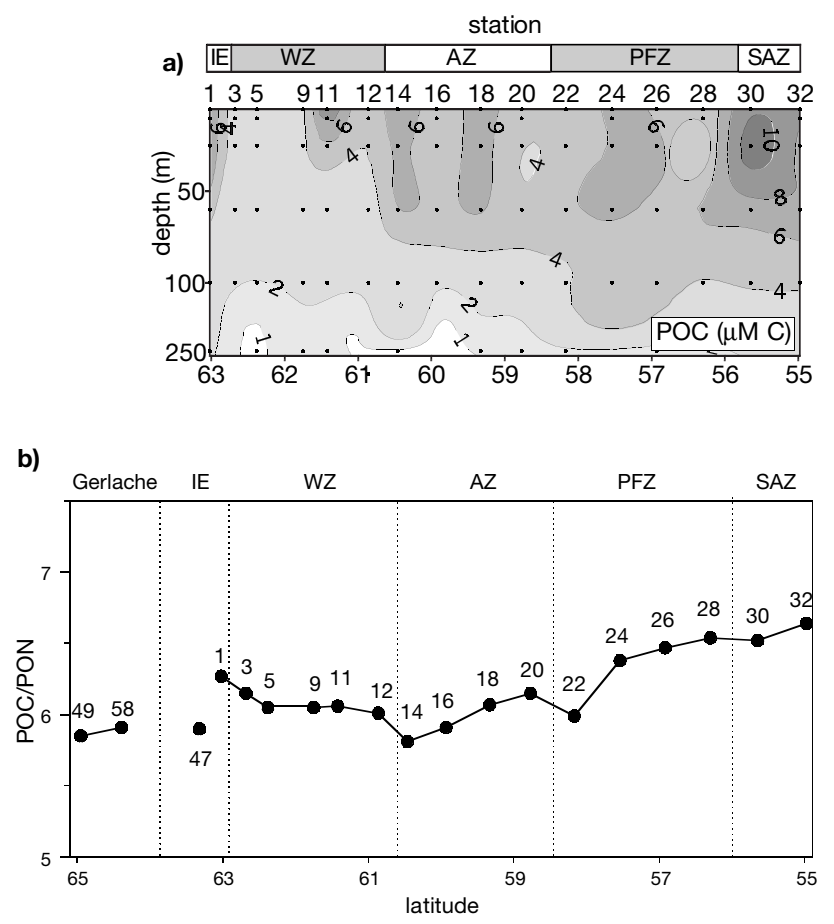

Fig. 4. Distribution of POC (a) and POC/PON (mol C/mol N) (b) in study area. Black dots in (a) represent sampling depths, numbers in (b) stations. Note that upper $100 \mathrm{~m}$ are expanded (×2) compared to the 100 to $250 \mathrm{~m}$ depth range

heterotrophs and detritus, the POC/chl a slope has traditionally been considered to provide a good estimate of the phytoplankton POC/chl a ratio (Banse 1974, 1977, Eppley et al. 1977, Nelson et al. 1989). These slopes were within the wide range of $\mathrm{POC} / \mathrm{chl}$ a ratios reported for Antarctic waters (between 11 and $416 \mathrm{~g} \mathrm{C}$ $\mathrm{g}^{-1}$ chl a: El Sayed \& Taguchi 1981, Palmisano et al. 1985). There was a clear inverse relationship between the average chl a concentration in the upper mixed layer and the POC/chl a slope. This could be due to an exponential increase in efficiency of POC production, in addition to the higher heterotrophic relative to autotrophic biomass (Gasol et al. 1997) and the higher proportion of detritus (Verity et al. 1996) in regions with lower chl a. Since POC and chl a correlate quite well in the various hydrographic regions (Table 1), we can roughly estimate the fraction of the POC pool which covaries with chl a by multiplying the slope of the corresponding regression by the average integrated chl a. This will be what we call the 'bioreactive fraction of $\mathrm{POC}^{\prime}\left(\mathrm{POC}_{\mathrm{B}}\right)$, which is susceptible to (but does not necessarily undergo) degradation. Our results (Table 1) indicate that $>75 \%$ of the POC pool in the Atlantic Sector of the Southern Ocean is $\mathrm{POC}_{\mathrm{B}}$, exceeding $80 \%$ in the chl a rich IE and Gerlache Strait regions.

POC and PON were extremely well related throughout the upper $250 \mathrm{~m}$ (POM sampling range); the linear correlation for all samples was high $(\mathrm{r}=0.99)$ and the $\mathrm{C} / \mathrm{N}$ slope of the linear regression (Model II) was

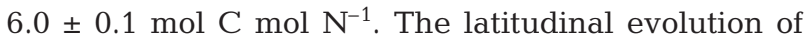
the $\mathrm{POC} / \mathrm{PON}$ ratio was characterised by values of $\sim 5.9 \mathrm{~mol} \mathrm{C} \mathrm{mol} \mathrm{N}{ }^{-1}$ in the Gerlache Strait, $\sim 6.1 \mathrm{~mol} \mathrm{C}$ mol $\mathrm{N}^{-1}$ throughout the Weddell Sea, and a clear in-

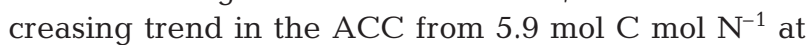
the WSF to $6.7 \mathrm{~mol} \mathrm{C} \mathrm{mol} \mathrm{N^{-1 }}$ in the SAZ (Fig. 4b). Therefore, all stations showed average $\mathrm{C} / \mathrm{N}$ ratios below the Redfield value of 6.7 (Anderson 1995). Nitrogen-rich materials have been traditionally considered as potentially available to organisms (Eppley et al. 1977, Copin-Montégut \& Copin-Montégut 1983). These C/N ratios are typical of net autotrophic systems (HolmHansen et al. 1989, Nelson et al. 1989), as also suggested by the elevated percentages of $\mathrm{POC}_{\mathrm{B}}$ (Table 1).

\section{DOC/POC relationships. Refractory versus potentially bioreactive fractions of DOC in upper ocean waters}

POC (Fig. 4a) and DOC (Fig. 5) distributions were remarkably parallel throughout the upper $250 \mathrm{~m}(\mathrm{r}=0.76$, $\mathrm{n}=90$ ). Maximum DOC values were observed in the upper mixed layer, with average concentrations ranging from $\sim 47 \mu \mathrm{M} \mathrm{C}$ in the $\mathrm{WZ}$ to $\sim 55 \mu \mathrm{M} \mathrm{C}$ in the SAZ

Table 1. Chlorophyll a (chl a)-POC relationships in the 6 regions occupied during Cruise HE052. Average integrated POC and chl a concentrations in the upper mixed layer, slope and $y$-intercept of the POC/chl a linear regressions (Model II: Sokal \& Rohlf 1995), correlation coefficient (r) and average percentage of POC covarying with chl a (\% POC $\left.{ }_{B}\right)$. IE: ice edge; WZ: Weddell Zone; AZ: Antarctic Zone; PFZ: Polar Front Zone; SAZ: Subantarctic Zone. POC $_{\mathrm{B}}=$ bioreactive POC $(=\operatorname{slope} \times \mathrm{chl} a)_{i} \% \mathrm{POC}_{\mathrm{B}}=$ $\mathrm{POC}_{\mathrm{B}} / \mathrm{POC}$

\begin{tabular}{|lccccrrr|}
\hline Region & POC $(\mu \mathrm{M} \mathrm{C})$ & $\mathrm{Chl}\left(\mathrm{mg} \mathrm{m}^{-3}\right)$ & Slope $\left(\mathrm{g} \mathrm{C} \mathrm{g}^{-1} \mathrm{chl} \mathrm{a}\right)$ & $y$-intercept $(\mu \mathrm{M} \mathrm{C})$ & $\mathrm{r}$ & POC $_{\mathrm{B}}(\mu \mathrm{M} \mathrm{C})$ & $\% \mathrm{POC}_{\mathrm{B}}$ \\
\hline IE & 8.0 & 1.7 & $47 \pm 4$ & $1.4 \pm 0.6$ & 0.91 & 6.5 & 81 \\
Gerlache & 14.1 & 5.1 & $28 \pm 2$ & $2.1 \pm 1.0$ & 0.88 & 11.8 & 83 \\
WZ & 3.4 & 0.5 & $62 \pm 4$ & $1.0 \pm 0.2$ & 0.94 & 2.5 & 74 \\
AZ & 4.9 & 0.6 & $75 \pm 8$ & $1.3 \pm 0.4$ & 0.87 & 3.7 & 76 \\
PFZ & 4.8 & 0.4 & $113 \pm 15$ & $1.2 \pm 0.5$ & 0.82 & 3.7 & 77 \\
SAZ & 7.9 & 1.3 & $55 \pm 8$ & $1.8 \pm 0.7$ & 0.90 & 6.0 & 76 \\
\hline
\end{tabular}




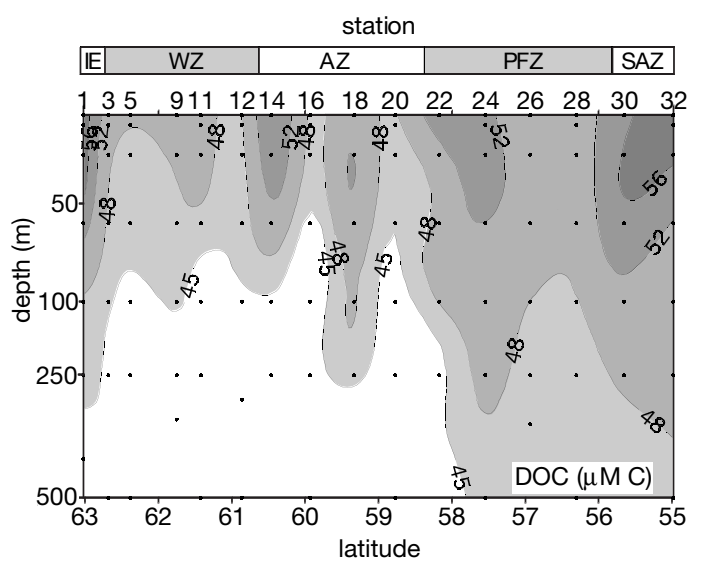

Fig. 5. Distribution of DOC along WOCE Line SR1b. Black dots represent sampling depths. Note that upper $100 \mathrm{~m}$ are expanded $(\times 2)$ compared to the 100 to $250 \mathrm{~m}$ depth range

(Table 2). These DOC levels were within the range found in other recent studies of ACC surface waters: 38 to $55 \mu \mathrm{M} \mathrm{C}$ in the Atlantic sector (Kähler et al. 1997), 52 to $63 \mu \mathrm{M} \mathrm{C}$ in the Indian sector (Wiebinga \& de Baar 1998), 45 to $55 \mu \mathrm{M} \mathrm{C}$ in the Australian sector (Ogawa et al. 1999), and 45 to $63 \mu \mathrm{M} \mathrm{C}$ in the Pacific sector of the Southern Ocean (Doval \& Hansell 2000). Local DOC maxima have also been found in association with icemelting areas (Kähler et al. 1997) and with the thermohaline fronts (PF, SAF) of the ACC (Wiebinga \& de Baar 1998, Doval \& Hansell 2000).

The most striking feature of the DOC distribution in the 100 to $500 \mathrm{~m}$ depth range is a significant increase in the concentration to the north of the PF: from $<45$ to $>48 \mu \mathrm{M}$ C. An equivalent raise was observed in the POC distributions also (Fig. 4a). Finally, DOC in deeper waters $(>1000 \mathrm{~m})$ was constant at $44 \pm 1 \mu \mathrm{M} \mathrm{C}$ (data not shown). This 'baseline' or 'refractory' DOC concentration is not significantly different from the most recent deep-sea DOC values reported for the Southern Ocean (Kähler et al. 1997, Carlson et al. 1998, Wiebinga \& de Baar 1998, Ogawa et al. 1999, Doval \&
Hansell 2000). Therefore, DOC levels in the Circumpolar Deep Water (CDW) transported by the ACC seem to be unchanged in the Atlantic, Indian and Pacific sectors of the Southern Ocean, as previously assumed by Hansell \& Carlson (1998) on the basis of the uniform distribution of other variables such as $\Delta^{14} \mathrm{CO}_{2}$.

DOC maxima occurred at the same positions as POC maxima, suggesting strong links between the origin and fate of the suspended and dissolved organic carbon pools. DOC and POC variability was also tightly coupled in the stratified waters of the Gerlache Strait (Fig. 3d,f), where the stock of organic matter in the upper mixed layer was larger than in the other study regions. Since DOC and POC in the upper mixed layer appears to covary, we proceeded to quantify the 'potentially bioreactive' fraction of the TOC pool $\left(\mathrm{TOC}_{\mathrm{B}}=\mathrm{DOC}_{\mathrm{B}}+\mathrm{POC}_{\mathrm{B}}\right)$ through an analysis of the correlation between TOC and $\mathrm{POC}_{\mathrm{B}}$ (which was calculated in Table 1) for all samples in the upper mixed layer. The TOC versus $\mathrm{POC}_{\mathrm{B}}$ scatter plot in Fig. 6 points to a wide range of possible TOC/POC $\mathrm{C}_{\mathrm{B}}$ relationships, with regression-slope values (Model II) ranging from 1.5 to 3.5. The $\mathrm{TOC} / \mathrm{POC}_{\mathrm{B}}$ slopes allow a rough estimate of the fraction of the TOC accumulated in the upper mixed layer that covaries with $\mathrm{POC}_{\mathrm{B}}$, i.e. $\mathrm{TOC}_{\mathrm{B}}$. Since the TOC pool includes $\mathrm{POC}_{\mathrm{B}}$, the $\mathrm{TOC} \mathrm{POC}_{\mathrm{B}}$ slopes have to be $\geq 1.0$. A value of 1.0 would indicate that $\mathrm{TOC}_{\mathrm{B}}$ would only be composed of $\mathrm{POC}_{\mathrm{B}}$. On the other hand, the slope values of 1.5 and 3.5 illustrated in Fig. 6 would correspond to extreme situations where the $\mathrm{POC}_{\mathrm{B}}$ represents 66 and $29 \%$ of the $\mathrm{TOC}_{\mathrm{B}}$ pool, respectively. Therefore, $\mathrm{DOC}_{\mathrm{B}}\left(=\mathrm{TOC}_{\mathrm{B}}-\mathrm{POC}_{\mathrm{B}}\right)$ would comprise 34 and $71 \%$ of the TOC $_{B}$ stock for these extreme cases, respectively.

Table 2 also shows the results of the $\mathrm{TOC} \mathrm{POC}_{\mathrm{B}}$ relationship for the 6 study regions occupied during the cruise. The lowest $\mathrm{TOC}_{\mathrm{POC}}$ slope $(1.7 \pm 0.1)$ was observed in the Gerlache Strait $\left(58 \%\right.$ POC $_{B}, 42 \%$ $\left.\mathrm{DOC}_{\mathrm{B}}\right)$. It was slightly higher $(2.3 \pm 0.3)$ in the proximity of the ice edge $\left(44 \% \mathrm{POC}_{\mathrm{B}}, 56 \% \mathrm{DOC}_{\mathrm{B}}\right)$, and increased to about $3.0 \pm 0.3$ in the open ocean waters

Table 2. TOC/POC $\mathrm{B}$ relationship in the 6 regions occupied during Cruise 'HE052'. Average integrated TOC, DOC and POC ${ }_{\mathrm{B}}$ in the upper mixed layer, slope of the TOC/POC $\mathrm{B}$ linear regressions (Model II: Sokal \& Rohlf 1995) correlation coefficient (r), average bioreactive TOC $\left(\mathrm{TOC}_{\mathrm{B}}\right)$, average percentage of bioreactive TOC in the TOC pool (\% TOC $\left.\mathrm{B}\right)$, average percentage of bioreactive $\mathrm{DOC}$ in the bioreactive TOC pool $\left(\% \mathrm{DOC}_{\mathrm{B}} / \mathrm{TOC}_{\mathrm{B}}\right)$ and average percentage of bioreactive DOC in the DOC pool $\left(\% \mathrm{DOC}_{\mathrm{B}}\right)$ are shown. $\mathrm{TOC}_{\mathrm{B}}=$ slope $\times \mathrm{POC}_{\mathrm{B}} \% \mathrm{TOC}_{\mathrm{B}}=\mathrm{TOC}_{\mathrm{B}} / \mathrm{TOC}_{i} \% \mathrm{DOC}_{\mathrm{B}}=\mathrm{DOC}_{\mathrm{B}} / \mathrm{DOC}$. Region abbreviations as in Table 1

\begin{tabular}{|lccccccccc|}
\hline Region & TOC $(\mu \mathrm{M})$ & DOC $(\mu \mathrm{M})$ & $\mathrm{POC}_{\mathrm{B}}(\mu \mathrm{M})$ & Slope & $\mathrm{r}$ & $\mathrm{TOC}_{\mathrm{B}}(\mu \mathrm{M})$ & $\% \mathrm{TOC}_{\mathrm{B}}$ & $\%_{\mathrm{DOC}_{\mathrm{B}} / \mathrm{TOC}_{\mathrm{B}}} \%_{\mathrm{DOC}} \mathrm{DOC}_{\mathrm{B} 5}$ \\
\hline IE & 61 & 53 & 6.5 & $2.3 \pm 0.3$ & 0.89 & 15 & 24 & 56 & 16 \\
Gerlache & 66 & 52 & 11.7 & $1.7 \pm 0.1$ & 0.96 & 20 & 30 & 42 & 16 \\
WZ & 50 & 47 & 2.6 & $2.9 \pm 0.3$ & 0.90 & 8 & 15 & 66 & 11 \\
AZ & 54 & 49 & 3.8 & $2.9 \pm 0.3$ & 0.91 & 11 & 20 & 65 & 15 \\
PFZ & 53 & 50 & 3.6 & $2.8 \pm 0.3$ & 0.89 & 10 & 20 & 65 \\
SAZ & 63 & 55 & 6.0 & $3.1 \pm 0.3$ & 0.97 & 18 & 29 & 68 & 13 \\
\hline
\end{tabular}




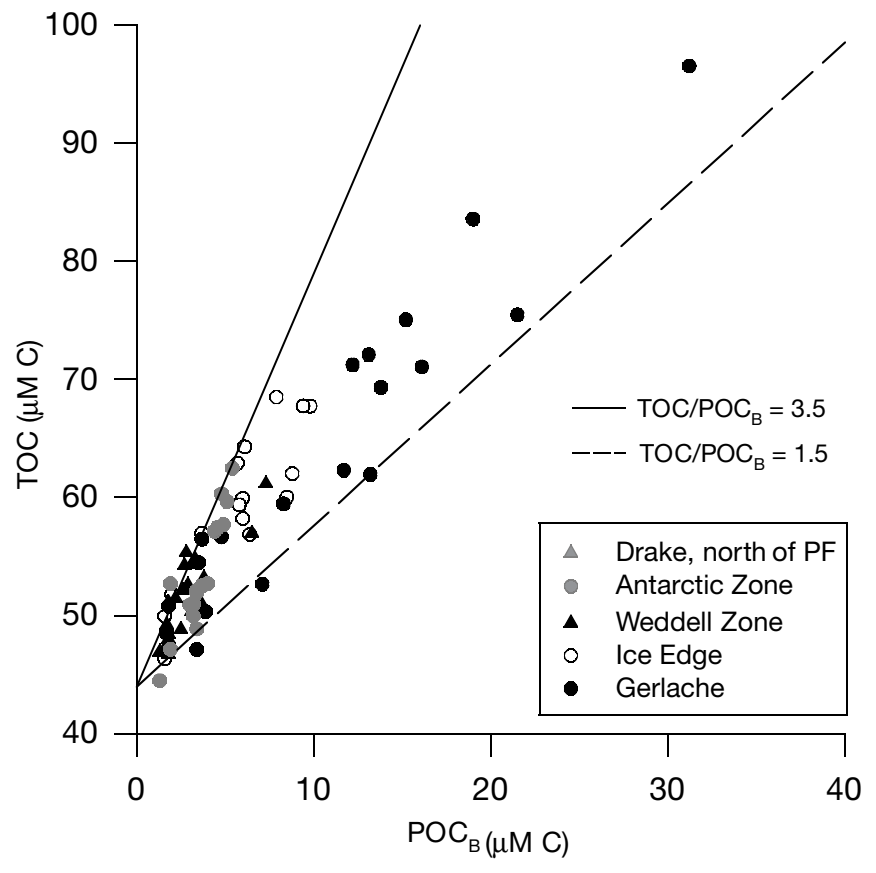

Fig. 6. TOC versus bioreactive $\mathrm{POC}\left(\mathrm{POC}_{\mathrm{B}}\right)$ plotted for all samples in the upper mixed layer. Continuous line: highest TOC/POC ${ }_{B}$ slope; dashed line: lowest $\mathrm{TOC} \mathrm{POC}_{\mathrm{B}}$ slope

of the Weddell Sea and Drake Passage $\left(34 \% \mathrm{POC}_{\mathrm{B}}\right.$, $66 \% \mathrm{DOC}_{\mathrm{B}}$ ).

Table 2 also shows that the contribution of $\mathrm{DOC}_{\mathrm{B}}$ to the $\mathrm{TOC}_{\mathrm{B}}$ pool tends to increase as the $\mathrm{POC}_{\mathrm{B}}$ pool decreases, i.e. as chl a levels decline. Therefore, it suggests that $\mathrm{TOC}_{\mathrm{B}}$ tends to accumulate in dissolved form in regions with reduced phytoplankton biomass, where the $\mathrm{POC} / \mathrm{chl}$ a ratio is higher and the $\mathrm{POC}_{\mathrm{B}} / \mathrm{POC}$ ratio is lower (Table 1). In this context, it has commonly been observed that POC represents a major fraction of the accumulated materials in surface waters of high chl a regions: 50 to $60 \%$ in the Iberian upwelling system (Álvarez-Salgado et al. 1999) and up to $89 \%$ during the spring bloom in the Ross Sea (Carlson et al. 1988). In contrast, POC represents $<25 \%$ of the accu- mulated organic carbon in the low chl a oligothrophic Mediterranean Sea (Copin-Montégut \& Avril 1993, Doval et al. 1999).

$\mathrm{TOC}_{\mathrm{B}}$ in the study regions was estimated by multiplying the $\mathrm{TOC} / \mathrm{POC}_{\mathrm{B}}$ slope and the corresponding average integrated $\mathrm{POC}_{\mathrm{B}}$ concentration (Table 2). $\mathrm{TOC}_{\mathrm{B}}$ concentration was maximum in the Gerlache Strait $(20 \mu \mathrm{M} \mathrm{C})$ and SAZ (18 $\mu \mathrm{M} \mathrm{C})$, where it represented $\sim 30 \%$ of the measured TOC. It was also relatively high at the ice edge and decreased in the other study zones. It was minimum in the WZ, with $8 \mu \mathrm{M} \mathrm{C}$ and only $15 \%$ of TOC. For comparison: TOC $_{B}$ amounted to 20 and $30 \%$ of the organic matter accumulated in the Bransfield and Gerlache Straits respectively during the austral summer of 1995 to 1996 (Doval et al. 2002), and Carlson et al. (1998) reported 15\% for the Ross Sea. On the other hand, $\mathrm{DOC}_{\mathrm{B}}(7 \pm 2 \mu \mathrm{M}$ C) represented $15 \%$ of the total DOC pool in the upper mixed layer, ranging from $11 \%$ in the WZ to $22 \%$ in the SAZ. This decrease in $\mathrm{DOC}_{\mathrm{B}}$ indicates a low accumulation of DOC in the study area, and is in agreement with the most recent studies of DOM in the Southern Ocean (Kähler et al. 1997, Carlson et al. 1998, Ogawa et al. 1999, Doval \& Hansell 2000).

\section{Primary versus bacterial production rates: assessing renewal times of $\mathrm{TOC}_{B}$}

Table 3 summarises the latitudinal evolution of primary production rates (PP), which were maximum in the highly productive IE and Gerlache Strait zones because of their substantial accumulation of chl a (Figs 2c \& 3b,d,f) in a relatively shallow upper mixed layer (Fig. 2b). A combination of high chl a and $E_{\mathrm{PUR}}$ values produced high PP rates (Eq. 3). This is also the reason behind the relatively high $\mathrm{PP}\left(\sim 1.0 \mathrm{~g} \mathrm{C} \mathrm{m}^{-2} \mathrm{~d}^{-1}\right)$ recorded for the SAZ. PP decreased in open-ocean waters to a minimum of $<0.5 \mathrm{~g} \mathrm{C} \mathrm{m}^{-2} \mathrm{~d}^{-1}$ in the PFZ, mainly due to low chl a values found in a deep (100 to $170 \mathrm{~m}$ ) upper mixed layer. These rates are in agree-

Table 3. Integrated area-average chlorophyll a (chl a), integrated $\mathrm{POC}_{\mathrm{B}}, \mathrm{TOC}_{\mathrm{B}}$, primary production (PP), bacterial heterotrophic production (BHP), bacterial carbon demand (BCD; assuming a bacterial gross growth efficiency, BGE, of $20 \%$ ), renewal times of $\mathrm{TOC}_{\mathrm{B}}, \tau_{20}$ (with BGE of $20 \%$ ) and $\tau_{10-40}$ (BGE of 10 to $40 \%$ ), and DOC $\mathrm{B}_{\mathrm{B}} / \mathrm{BCD}$ (assuming BGE of $20 \%$ ) in the upper mixed layer

(UML) of the 6 study regions during Cruise 'HE052' are shown. $\tau=$ TOC $_{B} /($ PP-BCD). Region abbreviations as in Table 1

\begin{tabular}{|lccccccccrr|}
\hline Region & $\begin{array}{c}\mathrm{UML} \\
(\mathrm{m})\end{array}$ & $\begin{array}{c}\mathrm{Chl} \mathrm{a} \\
\left(\mathrm{mg} \mathrm{m}^{-3}\right)\end{array}$ & $\begin{array}{c}\mathrm{POC}_{\mathrm{B}} \\
\left(\mathrm{g} \mathrm{C} \mathrm{m}^{-2}\right)\end{array}$ & $\begin{array}{c}\mathrm{TOC}_{\mathrm{B}} \\
\left(\mathrm{g} \mathrm{C} \mathrm{m}^{-2}\right)\end{array}$ & $\begin{array}{c}\mathrm{PP} \\
\left(\mathrm{g} \mathrm{C} \mathrm{m}^{-2} \mathrm{~d}^{-1}\right)\end{array}$ & $\begin{array}{c}\mathrm{BHP} \\
\left(\mathrm{g} \mathrm{C} \mathrm{m}^{-2} \mathrm{~d}^{-1}\right)\end{array}$ & $\begin{array}{c}\left.\mathrm{BCD}^{2} \mathrm{~g} \mathrm{~m}^{-2} \mathrm{~d}^{-1}\right) \\
(\mathrm{d})\end{array}$ & $\begin{array}{c}\tau_{20} \\
\tau_{10-40} \\
(\mathrm{~d})\end{array}$ & $\begin{array}{c}\mathrm{DOC} \\
(\mathrm{wk})\end{array}$ \\
\hline IE & 55 & 1.7 & 4.31 & 9.87 & 1.66 & 0.024 & 0.120 & 6 & $7-6$ & 6 \\
Gerlache & 49 & 5.1 & 7.01 & 12.28 & 2.05 & 0.029 & 0.144 & 6 & $7-6$ & 5 \\
WZ & 94 & 0.5 & 2.67 & 7.84 & 0.69 & 0.017 & 0.084 & 13 & $15-12$ & 9 \\
AZ & 104 & 0.6 & 4.44 & 12.71 & 0.91 & 0.018 & 0.092 & 15 & $17-15$ & 13 \\
PFZ & 133 & 0.4 & 5.65 & 15.65 & 0.49 & 0.017 & 0.087 & 39 & $49-35$ & 16 \\
SAZ & 78 & 1.3 & 5.39 & 16.76 & 1.15 & 0.025 & 0.214 & 16 & $19-15$ \\
\hline
\end{tabular}


ment with those found in most studies in the area (Bracher et al. 1999 and references there in, Figueiras et al. 1999, Park et al. 1999). Bacterial production rates (BHP: Table 3) showed the same latitudinal trend as PP rates, representing $<4 \%$ of $\mathrm{PP}$ in all the study regions. $\mathrm{BHP} / \mathrm{PP}$ ratios ranging between 0.01 and 0.10 have been recently found in the high-latitude areas of the central Arctic Sea (Rich et al. 1997) and the Ross Sea (Carlson et al. 1998). A low BHP/PP ratio (preliminary index for organic carbon processes by marine bacterioplankton) points to the likely accumulation of products of phytoplankton photosynthesis.

A rough estimate of the renewal time $(\tau)$ of $\mathrm{TOC}_{\mathrm{B}}$ in the upper mixed layer can be calculated by:

$$
\tau=\frac{\mathrm{POC}_{\mathrm{B}}+\mathrm{DOC}_{\mathrm{B}}}{\mathrm{PP}-\mathrm{BCD}}=\frac{\mathrm{POC}_{\mathrm{B}}+\mathrm{DOC}_{\mathrm{B}}}{\mathrm{PP}-\frac{\mathrm{BHP}}{0.20}}
$$

where the bacterial carbon demand $(\mathrm{BCD})$, i.e. the carbon that flows through bacterioplankton, has been calculated assuming an average bacterial growth efficiency (BGE) of $20 \%\left(\tau_{20}\right.$ : Table 3$)$. This lies between the values of 14 and 12 to $38 \%$ (Carlson et al. 1998, 1999) and 23 to $30 \%$ (Kähler et al. 1997) reported for Antarctic waters, and is very close to the median ocean estimate of $22 \%$ (del Giorgio \& Cole 1998). The photosynthetic parameters for calculating the daily PP rates are obtained from short ${ }^{14} \mathrm{C}$ incubations $(2 \mathrm{~h})$, so respiration of photo-assimiled ${ }^{14} \mathrm{C}$ during this short period can be considered negligible (e.g. Williams 1993, Joint et al. 2002). PP roughly represents the gross PP of organic matter, and is the prime source of both $\mathrm{POC}_{\mathrm{B}}$ and $\mathrm{DOC}_{\mathrm{B}}$ in the upper mixed layer. On the other hand, $\mathrm{BCD}$ is the prime sink of $\mathrm{DOC}_{\mathrm{B}}$ enabling the balancing of $\mathrm{TOC}_{\mathrm{B}}$ sources and sinks in the upper mixed layer. Since both PP and BHP rate estimates are representative for a period of $<24 \mathrm{~h}$, sedimentation and horizontal advection are not sinks relevant for consideration in Eq. (4). Therefore, it should be kept in mind that $\tau$ represents the time required to renew the $\mathrm{TOC}_{\mathrm{B}}$ pool if the initial conditions of negligible sedimentation and advection are maintained.

Renewal time, $\tau$, was only 1 wk in the highly productive waters of the IE and the Gerlache Strait, increasing to $2 \mathrm{wk}$ in open-ocean waters of the Weddell Sea and Drake Passage. The PFZ was an exception $(\tau>5 \mathrm{wk})$, because of the combination of a great excess of bioreactive materials in the $>100 \mathrm{~m}$ upper mixed layer (average $15.7 \mathrm{~g} \mathrm{C} \mathrm{m}^{-2}$ ) and a very low PP rate (average $<0.5 \mathrm{~g} \mathrm{C} \mathrm{m}^{-2} \mathrm{~d}^{-1}$ ). The interpretation of our results does not essentially alter when considering a broad range of BGE numbers, from 10 to $40 \%\left(\tau_{10-40}\right.$ : Table 3$)$. In the same way, underestimation of PP by 10 and $20 \%$ because of the exudation of ${ }^{14} \mathrm{C}$ during $\mathrm{PP}$ incubations; (e.g. Carlson et al. 1998) and overestimation by 0 to
$10 \%$ due to phytoplankton respiration does not result in significant differences in the estimated $\tau$ values. The whole range of parameters considered produces an error in the $\tau_{20}$ index of between 10 and $25 \%$ across the various study regions. The current literature considers as 'labile' organic material with turnover times of $<10 \mathrm{~d}$ (e.g. Kirchman et al. 1991, Norrman et al. 1995).

As suggested by the low BHP/PP ratio, the short $\mathrm{TOC}_{\mathrm{B}}$ renewal times resulted from the combination of relatively high PP rates and reduced bacterial activity. This suggests a 'malfunctioning' of the microbial loop not related to the availability of (1) inorganic macronutrients, which are in excess (Levitus et al. 1993) and in forms utilizable by bacteria (Kirchman 2000), or (2) organic carbon $\left(\mathrm{TOC}_{\mathrm{B}}\right)$. The low temperatures of Antarctic waters (Pomeroy \& Deibe 1986) (specifically temperature inhibition of the initial steps of POM degradation processes: Lancelot et al. 1989), microzooplankton grazing on bacteria (Bird \& Karl 1999) and/or the possible lag time between PP and BHP peaks (Lancelot et al. 1989, Karl et al. 1996) are the most probable reasons for the accumulation of DOC. Iron limitation of bacterial growth also cannot be ruled out (Pakulski et al. 1996). The $\mathrm{DOC}_{\mathrm{B}} / \mathrm{BCD}$ ratio (Table 3), representing the time that heterotrophic bacteria require to process the bioreactive DOC in the upper mixed layer, ranges from $5 \mathrm{wk}$ in the Gerlache Strait to 16 wk in the PFZ, assuming an average BGE of $20 \%$. Börsheim (2000) calculated the $\mathrm{DOC}_{\mathrm{B}} / \mathrm{BCD}$ ratio for the Greenland Sea in the Arctic to range from 1 to $13 \mathrm{wk}$, similar to the range that we calculated for the Antarctic.

\section{Conclusions}

The correlation between chlorophyll $a$ and dissolved and suspended organic carbon pools across contrasting coastal, ice edge and open-ocean waters of the Atlantic Sector of the Southern Ocean suggests that a considerable fraction (15 to $30 \%$ ) of the organic carbon in the upper mixed layer consists of the products of synthesis and early degradation of marine primary production. Maximum fractions of these potentially bioreactive materials are present in the highly productive coastal, ice edge and subantarctic regions. A rough calculation of their renewal times (usually $\leq 2 \mathrm{wk}$ ) can be made from measured primary and bacterial production rates. Reduced bacterial activity seems to be related to mechanisms other than substrate (nutrients, organic matter) limitation. The contribution of DOC to the organic matter accumulated in the upper mixed layer increased from the chl a-rich coastal and ice edge regions to the chl a-poor openocean waters. 
Acknowledgements. The authors wish to thank for their collaboration the crew and scientific parties who participated in Cruise HE052, aboard the 'BIO Hespérides'. Special thanks to A. F. Ríos and T. Rellán, who performed the POC/PON analyses, P. Pazos for assistance with on-board primary production measurements, and M. M. Sala for help with the bacterial determinations. A CSIC-Xunta Galicia post-doctoral fellowship allowed M.D.D. to carry out this work. Financial support allowing participation in the project 'DHARMA' came from the Spanish CICYT, grant numbers AMT1998-1265-E and ANT97-1155.

\section{LITERATURE CITED}

Álvarez-Salgado XA, Doval MD, Pérez FF (1999) Dissolved organic matter in shelf waters off the Ría de Vigo (NW Iberian upwelling system). J Mar Syst 18:383-394

Anderson LA (1995) On the hydrogen and oxygen content of marine phytoplankton. Deep-Sea Res Part I Oceanogr Res Pap 42:1675-1680

Banse K (1974) On the interpretation of data for the carbonto-nitrogen ratio of phytoplankton. Limnol Oceanogr 19: 695-699

Banse K (1977) Determining the carbon-to-chlorophyll ratio of natural phytoplankton. Mar Biol 41:199-212

Bird DF, Karl DM (1999) Uncoupling of bacteria and phytoplankton during the austral spring bloom in Gerlache Strait, Antarctic Peninsula. Aquat Microb Ecol 19:13-27

Bodineau L, Thoumelin G, Wartel M (1999) Fluxes and seasonal changes in composition of organic matter in the English Channel. Cont Shelf Res 19:2101-2119

Börsheim KY (2000) Bacterial production rates and concentrations of organic carbon at the end of the growing season in the Greenland Sea. Aquat Microb Ecol 21:115-123

Bracher AU, Kroon BMA, Lucas MI (1999) Primary production, physiological state and composition of phytoplankton in the Atlantic sector of the Southern Ocean. Mar Ecol Prog Ser 190:1-16

Bronk DA, Glibert PM, Ward BB (1994) Nitrogen uptake, dissolved organic nitrogen release, and new production. Science 265:1843-1846

Carlson CA, Ducklow HW, Michaels AF (1994) Annual flux of dissolved organic carbon from the euphotic zone in the North-western Sargasso Sea. Nature 371:405-408

Carlson CA, Ducklow HW, Hansell DA, Walker OS Jr (1998) Organic carbon partitioning during spring phytoplankton blooms in the Ross Sea polynya and the Sargasso Sea. Limnol Oceanogr 43:375-386

Carlson CA, Bates NR, Ducklow HW, Hansell DA (1999) Estimation of bacterial respiration and growth efficiency in the Ross Sea, Antarctica. Aquat Microb Ecol 19:229-244

Copin-Montégut G, Avril B (1993) Vertical distribution and temporal variation of dissolved organic carbon in the North Western Mediterranean Sea. Deep-Sea Res Part I Oceanogr Res Pap 40:1963-1972

Copin-Montégut C, Copin-Montégut G (1983) Stoichiometry of carbon, nitrogen, and phosphorus in marine particulate matter. Deep-Sea Res Part I Oceanogr Res Pap 30:31-46

del Giorgio PA, Cole JJ (1998) Bacterial growth efficiency in natural aquatic systems. Annu Rev Ecol Syst 29:503-541

Doval MD, Hansell D (2000) Organic carbon and apparent oxygen utilisation in the western South Pacific and the Central Indian Oceans. Mar Chem 68:249-264

Doval MD, Pérez FF, Berdalet E (1999) Dissolved and particulate organic carbon and nitrogen in the Northwestern Mediterranean. Deep-Sea Res Part I Oceanogr Res Pap 46:511-527
Doval MD, Álvarez-Salgado XA, Castro CG, Pérez FF (2002) Dissolved organic carbon distributions in the Bransfield and Gerlache Straits, Antarctica. Deep-Sea Res Part II Top Stud Oceanogr (in press)

Dubinsky Z (1980) Light utilization efficiency in natural phytoplankton communities. In: Falkowski PJ (ed) Primary productivity in the sea. Plenum Publishing Corp, New York, p 83-97

El-Sayed SZ, Taguchi S (1981) Primary production and standing crop of phytoplankton along the ice-edge in the Weddell Sea. Deep-Sea Res 28A:1017-1032

Eppley RW, Peterson BJ (1979) Particulate organic matter flux and planktonic new production in the deep ocean. Nature 282:677-680

Eppley RW, Harrison WG, Chisholm SW, Steward E (1977) Particulate organic matter in surface waters off Southern California and its relationship to phytoplankton. J Mar Res 35:671-696

Figueiras FG, Arbones B, Estrada M (1999) Implications of bio-optical modelling of phytoplankton photosynthesis in Antarctic waters: further evidence of no light limitation in the Bransfield strait. Limnol Oceanogr 44:1599-1608

García MA (1996) BIO Hesperides covered WOCE SR1b in February 1995. Int WOCE Newsl 23:33-35

Gasol JM, del Giorgio PA (2000) Using flow cytometry for counting natural planktonic bacteria and understanding the structure of planktonic bacterial communities. Sci Mar 64:197-224

Gasol JM, del Giorgio PA, Duarte CM (1997) Biomass distribution in marine plakton communities. Limnol Oceanogr 42:1353-1363

Gordon AL, Georgi DT, Taylor HW (1977) Antarctic Polar Front Zone in the Western Scotia Sea-summer 1975. J Phys Oceanogr 57:309-328

Hansell DA, Carlson CA (1998) Deep ocean gradients in concentration of dissolved organic carbon. Nature 395:263-266

Holm-Hansen O, Mitchell BG, Hewes CD, Karl DM (1989) Phytoplankton blooms in the vicinity of Palmer Station, Antarctica. Polar Biol 10:49-57

Hung JJ, Lin PL, Liu KK (2000) Dissolved and particulate organic carbon in the southern East China Sea. Cont Shelf Res 20:545-569

Joint I,Gromm SB, Wollast R, Chou L, Tilstone GH, Figueiras FG, Loijens M, Smyth TJ (2001) The response of phytoplankton production to periodic upwelling and relaxation events at the Iberian shelf break: estimates by the ${ }^{14} \mathrm{C}$ method and by remote sensing. J Mar Sys (in press)

Kähler P, Björnsen PK, Lochte K, Antia A (1997) Dissolved organic matter and its utilization by bacteria during spring in the Southern Ocean. Deep-Sea Res Part II Top Stud Oceanogr 44:341-353

Karl DM, Christian JR, Dore JE (1996) Microbiological oceanography in the region west of the Antarctic Peninsula: microbial dynamics, nitrogen cycle and carbon flux. Antarct Res Ser 70:303-332

Kirchman DL (1993) Leucine incorporation as a measure of biomass production by heterotrophic bacteria. In: Kemp PF, Sherr BF, Sherr EB, Cole JJ (eds) Handbook of methods in aquatic microbial ecology. Lewis Publishers, Boca Raton, FL, p 509-512

Kirchman DL (2000) Uptake and regeneration of inorganic nutrients by marine heterotrophic bacteria, In: Kirchman DL (ed) Microbial ecology of the ocean. Wiley, New York, p 261-288

Kirchman DL, Suzuki Y, Garside C, Ducklow HW (1991) High turnover rates of dissolved organic carbon during a spring phytoplankton bloom. Nature 352:612-614 
Kirchman DL, Lancelot C, Fasham M, Legendre L, Radach G, Scott M (1993) Dissolved organic material in biogeochemical models of the ocean. In: Evans GT, Fasham MJR (eds) Towards a model of ocean biogeochemical processes, Ser I: Global environmental change. Springer-Verlag, Berlin, p 209-225

Lancelot C, Billen G, Mathot S (1989) Ecophysiology of phytoand bacterioplankton growth in the Southern Ocean. In: Caschetto S (ed) Belgian Scientific Research programme on Antarctica-scientific results of phase I (10/198501/1989): 1. Plankton ecology. Science Policy Office of Belgium, Brussels, p 05/1-97

Le Fèvre J, Trèguer P (1998) Preface of carbon fluxes and dynamic processes in the Southern Ocean: present and past. J Mar Syst 17:1-3

Levitus S, Conkright ME, Reid JL, Naijar RG, Mantyla A (1993) Distribution of nitrate, phosphate and silicate in the world oceans. Prog Oceanogr 31:245-273

Melnikov IA (1998) Winter production of sea ice algae in the western Weddell Sea. J Mar Syst 17:195-205

Millard RC, Owens WB, Fofonoff NP (1990) On the calculations of the Brunt-Väisälä frequency. Deep-Sea Res Part I Oceanogr Res Pap 37:167-181

Murphy EJ, Boyd PW, Leakey RJG, Atkinson A, Edwards ES, Robinson C, Priddle J, Bury SJ, Robins DB, Burkill PH, Savidge G, Owens NPJ, Turner D (1998) Carbon flux in ice-ocean-plankton systems of the Bellingshausen Sea during a period of ice retreat. J Mar Syst $17: 207-227$

Nelson DM, Smith WO, Muench RD, Gordon LI, Sullivan CW, Husby DM (1989) Particulate matter and nutrient distribution in the ice-edge zone of the Weddell Sea: relationship to hydrography during late summer. Deep-Sea Res 36: 191-209

Niiler PP, Amos A, Hu JH (1991) Water masses and $200 \mathrm{~m}$ relative geostrophic circulation in the western Bransfield Strait region. Deep-Sea Res Part II Top Stud Oceanogr 38: 943-961

Norrman B, Zweifel UL, Hopkinson CS Jr, Fry B (1995) Production and utilisation of dissolved organic carbon during an experimental diatom bloom. Limnol Oceanogr 40: 898-907

Nowlin WD Jr, Whitworth T III, Pillsbury RD (1977) Structure and transport of the Antarctic circumpolar current at Drake Passage from short-term measurements. J Phys Oceanogr 7:788-802

Ogawa H, Fukuda R, Koike I (1999) Vertical distributions of dissolved organic carbon and nitrogen in the Southern Ocean. Deep-Sea Res Part I Oceanogr Res Pap 46: 1809-1826

Pakulski JD, Coffin RB, Kelley CA, Holder SL, Downer R, Aas P, Lyons MM, Jeffrey WH (1996) Iron stimulation of Antarctic bacteria. Nature 383:133-134

Palmisano AC, Soohoo JB, Sullivan CW (1985) Photosynthesis-irradiance relationships in sea ice microalgae from McMurdo Sound, Antarctica. J Phycol 21:341-346

Park MG, Yang SR, Kang SH, Chung KH, Shim JH (1999) Phytoplankton biomass and primary production in the

Editorial responsibility: Otto Kinne (Editor),

Oldendorf/Luhe, Germany marginal ice zone of the northwestern Weddell Sea during austral summer. Polar Biol 21:251-261

Peterson RG, Stramma L (1991) Upper level circulation in the South Atlantic Ocean. Prog Oceanogr 26:1-73

Pomeroy LR, Deibel D (1986) Temperature regulation of bacterial activity during the spring bloom in Newfoundland coastal waters. Science 233:359-361

Rich J, Gosselin M, Sherr E, Sherr B, Kirchman DL (1997) High bacterial production, uptake and concentrations of dissolved organic matter in the Central Arctic Ocean. Deep-Sea Res Part II Top Stud Oceanogr 44:1645-1663

Riemann B, Bjørnsen PK, Newell SY, Fallon RD (1987) Calculation of cell production by coastal marine bacteria based on measured incorporation of $\left[{ }^{3} \mathrm{H}\right]$-thymidine. Limnol Oceanogr 32:471-476

Sanders R, Jickells T (2000) Total organic nutrients in Drake Passage. Deep-Sea Res Part I Oceanogr Res Pap 47: 997-1014

Smith DC, Azam F (1992) A simple, economical method for measuring bacterial protein synthesis rates in seawater using ${ }^{3} \mathrm{H}$-leucine. Mar Microb Food Webs 6:107-114

Smith WO, Nelson DM (1986) The importance of the ice-edge phytoplankton blooms in the Southern Ocean. BioScience 36:251-257

Sokal RR, Rohlf FJ (1995) Biometry. The principles and practice of statistics in biological research, 3rd edn. WH Freeman \& Co, New York

Sullivan CW, McClain CR, Comiso JC, Smith WO (1988) Phytoplankton standing crops within an Antarctic iceedge assessed by satellite remote sensing. J Geophys Res 93:12487-12498

Toggweiler JR (1989) Is the downward dissolved organic matter (DOM) flux important in carbon transport? In: Berger WH, Smatecek VS, Wefer G (eds) Productivity of the ocean: present and past. John Wiley, Chichester, p 65-83

Tréguer P, Jacques G (1992) Dynamics of nutrients and phytoplankton, fluxes of carbon, nitrogen and silicon in the Antarctic Ocean. Polar Biol 12:149-162

UNESCO (1985) The international system of units (SI) in oceanography. UNESCO Tech Pap Mar Sci 45, 124 pp

Verity PG, Beatty TM, Williams SC (1996) Visualization and quantification of plankton and detritus using digital confocal microscopy. Aquat Microb Ecol 10:55-67

Webb WL, Newton M, Starr D (1974) Carbon dioxide exchange of Alnus rubra: a mathematical model. Oecologia (Berl) 17:281-291

Wiebinga CJ, de Baar HJW (1998) Determination of the distribution of dissolved organic carbon in the Indian sector of the Southern Ocean. Mar Chem 61:185-201

Williams PJLeB (1993) Chemical and tracer methods of measuring plankton production. ICES Mar Sci Symp 197:20-36

Whitworth T III, Nowlin WD Jr, Orsi AH, Locarnini RA, Smith SG (1994) Weddell Sea Shelf water in the Bransfield Strait and Weddell-Scotia confluence. Deep-Sea Res Part I Oceanogr Res Pap 41:629-641

Yentsch CS, Menzel DW (1963) A method for the determination of phytoplankton chlorophyll and phaeophytin by fluorescence. Deep-Sea Res 10:221-231

Submitted: October 23, 2000; Accepted: February 1, 2001

Proofs received from author(s): November 9, 2001 